\title{
PENGARUH PENGGUNAAN DAUN MINT(Mentha piperita L.) BENTUK TEPUNG SEBAGAI PAKAN TAMBAHAN TERHADAP KUALITAS KARKAS AYAM PEDAGING
}

\author{
Effect of Mint Leaf (Mentha piperita L.) Powder as Feed Additive on Carcass \\ Quality of Broiler
Irfan H. Djunaidi ${ }^{1)}$, Eko Widodo ${ }^{1)}$ dan Diyanti Ayu Apriana ${ }^{2)}$
1) Dosen Minat Nutrisi dan Makanan Ternak, Fakultas Peternakan, Universitas Brawijaya, Malang-65145, Indonesia
${ }^{2)}$ Mahasiswa Fakultas Peternakan, Universitas Brawijaya, Malang-65145, Indonesia
Email: irjuna@ub.ac.id

\begin{abstract}
ABSTRAK
Penelitian ini bertujuan untuk mengetahui pengaruh penggunaan fitobiotik daun mint (Mentha piperita L.) bentuk tepung sebagai pakan tambahan terhadap karkas ayam pedaging. Materi yang digunakan adalah 200 ekor DOC jantan dengan koefisien keragaman 9,69\%. Metode yang digunakan adalah percobaan lapang dengan Rancangan Acak Lengkap (RAL) yang terdiri dari 5 perlakuan dan 5 ulangan, setiap ulangan menggunakan 8 ekor ayam pedaging. Adapun perlakuan yang digunakan $\mathrm{PO}^{+}$(pakan basal $+0,01 \%$ antibiotik $\mathrm{Zn}$ Bacitracin), $P 0^{-}$(pakan basal $+0 \%$ tepung daun mint), $P 1$ (pakan basal $+0,5 \%$ tepung daun mint), P2 (pakan basal $+1 \%$ tepung daun mint) dan P3 (pakan basal $+1,5 \%$ tepung daun mint). Variabel yang diamati meliputi persentase karkas, persentase lemak abdominal dan warna daging. Data yang diperoleh dianalisis menggunakan analisis ragam dan apabila terdapat perbedaan dilanjutkan uji Jarak Berganda Duncan's. Hasil penelitian menunjukkan bahwa perlakuan tidak berpengaruh nyata $(P>0,05)$ terhadap persentase karkas, persentase lemak abdominal dan warna daging. Disimpulkan bahwa penambahan tepung daun mint sampai level 1,5\% sebagai pakan tambahan belum dapat memperbaiki kualitas karkas ayam pedaging.
\end{abstract}

Kata kunci: Tepung daun mint, kualitas karkas ayam pedaging

How to Cite :

Djunaidi, I. H., Widodo, Eko., \& Apriana, D. A. (2018). Pengaruh Penggunaan Daun Mint (Mentha Piperita L.) Bentuk Tepung Sebagai Pakan Tambahan Terhadap Kualitas Karkas Ayam Pedaging. Jurnal Nutrisi Ternak Tropis, 1 (1) 1-8
*Corresponding author :

Irfan H. Djunaidi

Email : irjuna@ub.ac.id

Faculty of Animal Science, Brawijaya University,

Veteran Street, Malang, East Java, Indonesia. 65145 


\section{ABSTRACT}

The researchaimed to determine the effectofmint leaf (Mentha piperita L.) powder as feed additive on carcass quality of broiler. The materials were 200 male broilers of Day Old Chick (DOC) with $9.69 \%$ coefficient of variability. The method was field experiment arranged in Completely Randomized Design (CRD) with 5 treatments and 5 replacements, with 8 chicks in each unit. Treatments were $\mathrm{PO}^{+}$(basal diet $+0.01 \%$ antibiotic $\mathrm{Zn}$ Bacitracin), P0-(basal diet $+0 \%$ mint leaf powder), $P 1$ (basal diet $+0.5 \%$ mint leaf powder), $P 2$ (basal diet $+1 \%$ mint leaf powder) and P3 (basal diet $+1.5 \%$ mint leaf powder). The variables observed were the percentages of carcass and abdominal fat and meat color. Data were analyzed by using Analysis of Variance and if treatments showed significant differences then it was continued by Duncan's Multiple Range Test (DMRT). The result showed that the treatments had no significant effects $(P>0.05)$ on percentages of carcass and abdominal fat and meat color. The conclusion was addition of mint leaf powder up to $1.5 \%$ as addition feed can't improve carcass quality of broiler.

Keywords : Mint leaf powder, carcass quality of broiler

\section{PENDAHULUAN}

Keberhasilan usaha peternakan ayam pedaging salah satunya ditentukan oleh pakan yang diberikan. Pakan menyumbang komponen terbesar mencapai 60-70\% dari biaya yang dikeluarkan. Peternak umumnya menggunakan pakan komersial selain harganya yang relatif mahal didalamnya terkandung feed additive seperti hormon, antibiotikdan sebagainya yang dapat memacu pertumbuhan dan meningkatkan performa ayam pedaging. Penggunaan antibiotik jangka panjang dapat meninggalkan residu kimia pada produk peternakan unggas baik daging maupun telur. Oleh karena itu perlu dicarikan solusi untuk mengatasi permasalahan ini yaitu dengan mengganti penggunaan antibiotik dengan feed additive alami.

Feed additive merupakan suatu bahan yang ditambahkan dalam pakan dengan jumlah sedikit dan bertujuan untuk meningkatkan laju pertumbuhan dan memperbaiki efisiensi penggunaan pakan. Salah satu tanaman yang dapat digunakan sebagai feed additive alamiyaitu daun mint (Mentha piperita L.).

Daun mint memiliki kandungan antioksidan tinggi yang bersifat antimikroba, antitumor dan antialergenik (Perez, et al., 2014). Khempaka, et al.
(2013) menambahkan minyak atisiri daun mint meliputi mentol, mentonecanvone, methyl acetate dan peperitone yang berperan sebagai antioksidan, merangsang sekresi asam empedu, memperbaiki laju pertumbuhan, mengurangi produksi amonia serta menghambat pertumbuhan mikroba patogen seperti Escherichia coli, Staphylococcus aureus, Salmonella enteridis dan Candida albicans.

Siswi, Widodo dan Djunaidi (2013) melaporkan, minyak atsiri berperan untuk membantu kerja enzim pencernaan dengan cara merangsang dinding kantong empedu mensekresikan cairan empedu dan merangsang keluarnya getah pankreas seperti enzim amilase, protease dan lipase yang berfungsi untuk mencerna karbohidrat, protein dan lemak sehingga meningkatkan laju pakan dan pertumbuhan menyebabkan naiknya produksi daging.

Berdasarkan kajian pustaka mengenai manfaat tanaman herbal yang dapat digunakan sebagai aditif pakan alami dan berkhasiat untuk memperbaiki kondisi saluran pencernaan, meningkatkan kecernaan nutrisi pakan serta konversi pakan, sehingga perlu dikaji pengaruh penggunaan daun mint (Mentha piperita L.) bentuk tepung sebagai pakan tambahan terhadap karkas ayam pedaging. 


\section{MATERI DAN METODE}

Penelitian ini dilaksanakan pada tanggal 24 Juli sampai 28 Agustus 2017 di Desa Tegalgondo, Karangploso, Malang. Analisis bahan pakan fase starter dan finisher dilakukan di Laboratorium Nutrisi dan Makanan Ternak Fakultas Peternakan Universitas Brawijaya. Pengujian dan analisa warna daging dilakukan di Laboratorium Pengujian Mutu dan Keamanan Pangan Fakultas Teknologi Pertanian Universitas Brawijaya.

Materi yang digunakan adalah 200 ekor Day Old Chick (DOC) ayam pedaging jantan strain Lohman MB 202 dari PT. Japfa Comfeed Indonesia Tbk yang dipelihara 35 hari dengan rata-rata bobot badan awal 46,10 $\pm 4,47$ g/ekor dan koefisien keragaman $9,69 \%$ yang ditempatkan pada 25 petak kandang open house sistem litter bersekat bambu berukuran 100 x 100 x $70 \mathrm{~cm}$.

Peralatan yang digunakan adalah tempat pakan, tempat minum, pemanas, lampu, thermometer dan timbangan digital kapasitas $5 \mathrm{~kg}$. Pakan yang digunakan berupa pakan starter dan finisher yang diransum sendiri. Pemberian pakan dan air minum dilakukan secara ad libitum.

Tabel 1. Komposisi pakan berdasarkan periode pemeliharaan dan kandungan pakan basal

\begin{tabular}{lcc}
\hline \multicolumn{1}{c}{ Bahan Pakan } & Periode Starter $(\%)^{*}$ & Periode Finisher $(\%)^{*}$ \\
\hline Jagung kuning & 52,65 & 61,00 \\
Bungkil kedelai & 37,00 & 22,11 \\
Bekatul & 0,00 & 2,00 \\
MBM & 6,20 & 10,00 \\
Minyak kelapa & 3,04 & 4,40 \\
Garam & 0,10 & 0,19 \\
Diposfat & 0,20 & 0,00 \\
Lisin & 0,13 & 0,16 \\
Methionin & 0,20 & 0,14 \\
Kapur & 0,48 & 0,00 \\
\hline Total & 100 & 100 \\
\hline & Periode Starter & Periode Finisher \\
\hline Energi metabolis $(\mathrm{Kkal} / \mathrm{Kg})$ & 3000,33 & 3205,56 \\
Protein kasar (\%) & 23,01 & 19,50 \\
Lemak kasar $(\%)$ & 5,37 & 7,33 \\
Serat kasar (\%) & 4,90 & 4,57 \\
Kalsium $(\%)$ & 0,96 & 1,08 \\
Fosfor (\%) & 0,61 & 0,72 \\
Methionin (\%) & 0,56 & 0,47 \\
Lisin (\%) & 1,44 & 1,15 \\
\hline
\end{tabular}

*) Dibuat menggunakan software UB Feed-Poultry 2016

Feed additive alami yang digunakan yaitu tepung daun mint (TDM). Tanaman mint segar dibeli dari Bapak Aji yang beralamat di Desa Bumiaji, Kota Batu. Pembuatan TDMdiawali dengan melayukan daun mint dengan dikering anginkan sampai kering, kemudian dihaluskan menggunakan blender, diayak dan hasil akhirnya yang berupa TDM siap digunakan. Komposisi pakan dan kandungan nutrisi yang digunakan dapat dilihat pada Tabel 1 .

Metode penelitian yang digunakan adalah percobaan lapang dengan menggunakan Rancangan Acak Lengkap (RAL) terdiri dari 5 perlakuan dan 5 ulangan, setiap ulangan menggunakan 8 ekor ayam pedaging. Perlakuan yang digunakan adalah sebagai berikut: 
$\mathrm{P}^{+} \quad$ : Pakan basal $+0,01 \%$ antibiotik $\mathrm{Zn}$ Bacitracin

$\mathrm{P}^{-} \quad$ : Pakan basal + $0 \%$ TDM

P1 : Pakan basal + 0,5\% TDM

P2 : Pakan basal + 1\% TDM

P3 : Pakan basal + 1,5\% TDM

Pakan perlakuan diberikan dengan cara mencampur pakan basal dengan TDM sesuai dengan level, kemudian diujicobakan ke ternak. DOC terlebih dahulu dilakukan penimbangan bobot badan awal, kemudian dimasukkan dalam kandang pemeliharaan yang telah dilakukan pengacakan. Variabel yang diamati adalah persentase karkas, persentase lemak abdominal dan warna daging.

Pengambilan data kualitas karkas dilakukan pada hari ke 36 penelitian, diambil dari setiap petak yang memiliki bobot badan yang hampir sama dengan bobot badan rata-rata. Sampel karkas diperoleh dari bobot hidup yang dikurangi bobot non karkas (bulu, kepala, leher, kaki, organ dalam darah), selanjutnya ditimbang.Sampel lemak abdominal diambil dari lemak disekeliling gizzard, dinding perut dan kloaka. Sampel warna daging diambil dari bagian dada, kemudian diukur dengan menggunakan alat Chromatometer MinoltaColour Reader dengan metode sistem Hunter/L*, $\mathrm{a}^{*}, \mathrm{~b}^{*}$ berdasarkan Weaver (1996).

Data yang diperoleh dari hasil lapang diolah dengan menggunakan bantuan miscrosoft excel dilanjutkan dengan analisis statistik menggunakan analisis ragam (ANOVA) dengan metode percobaan Rancangan Acak Lengkap (RAL). Apabila diperoleh hasil yang berbeda nyata $(\mathrm{P}<0,05)$ atau berbeda sangat nyata $(\mathrm{P}<0,01)$ maka dilanjutkan dengan uji jarak berganda Duncan's.

\section{HASIL DAN PEMBAHASAN}

Pengaruh penggunaan daun mint (Mentha piperita L.) bentuk tepung sebagai pakan tambahan terhadap kualitas karkas ayam pedaging secara lengkap ditampilkan pada Tabel 2.

Tabel 2. Pengaruh perlakuan terhadap karkas ayam pedaging

\begin{tabular}{lccccc}
\hline \multirow{2}{*}{ Perlakuan } & \multicolumn{5}{c}{ Variabel } \\
\cline { 2 - 6 } & \multirow{2}{*}{ Karkas (\%) } & $\begin{array}{c}\text { Lemak } \\
\text { Abdominal }(\%)\end{array}$ & $\mathrm{L}^{*}$ & $\mathrm{a}^{*}$ & $\mathrm{~b}^{*}$ \\
\cline { 4 - 6 } & & $1,26 \pm 0,43$ & $40,54 \pm 1,57$ & $22,94 \pm 0,82$ & $6,44 \pm 1,90$ \\
$\mathrm{P}^{+1)}$ & $61,26 \pm 4,70$ & $1,55 \pm 0,57$ & $39,28 \pm 1,69$ & $22,30 \pm 1,81$ & $4,00 \pm 0,80$ \\
$\mathrm{P}^{-}$ & $60,34 \pm 1,84$ & $1,67 \pm 0,41$ & $39,22 \pm 1,70$ & $23,92 \pm 2,11$ & $4,26 \pm 2,40$ \\
$\mathrm{P} 1$ & $61,34 \pm 2,90$ & $1,21 \pm 0,24$ & $38,84 \pm 1,74$ & $26,30 \pm 4,86$ & $2,30 \pm 1,70$ \\
$\mathrm{P} 2$ & $59,98 \pm 3,00$ & $1,53 \pm 0,28$ & $39,54 \pm 1,74$ & $24,32 \pm 2,28$ & $4,54 \pm 2,40$ \\
\hline P3 & $64,03 \pm 4,13$ & &
\end{tabular}

Keterangan $: L^{*}=$ Kecerahan, $a^{*}=$ Kemerahan, $b^{*}=$ Kekuningan

1) $=$ Perlakuan pembanding

\section{Pengaruh Perlakuan terhadap Persentase Karkas Ayam Pedaging}

Tabel 2. menunjukkan nilai rata-rata persentase karkas ayam pedaging dari yang tertinggi sampai terendah secara berurutan yaitu P3 sebesar $(64,03 \pm 4,13) \%, \quad \mathrm{P} 1$ $(61,34 \pm 2,90) \%, \quad \mathrm{P}^{+}(61,26 \pm 4,70) \%, \quad \mathrm{P}^{-}$ $(60,34 \pm 1,84) \%$, dan P2 $(59,98 \pm 3,00) \%$. Hasil analisis sidik ragam menunjukkan bahwa pemberian TDM sampai level 1,5\% memberikan pengaruh yang tidak berbeda nyata $(\mathrm{P}>0,05)$ terhadap persentase karkas ayam pedaging.

Persentase karkas yang tidak berbeda diduga disebabkan kandungan aktif daun mint yang berupa minyak atsiri kurang berperan dalam proses pencernaan dan hanya berpengaruh terhadap kesehatan ternak, seperti yang diketahui bahwa daun mint memiliki sifat biologis berupa antimikroba untuk melawan bakteri patogen seperti Escherichia coli, 
Staphylococcus aureus, Pseudomonas aeruginosa, Pitrosporum ovale, Candida albicans, dan Propionibacterium acnes (Tsai, et al., 2013) tetapi tidak berpengaruh terhadap persentase karkas.

Penelitian ini menggunakan TDM level $0,5-1,5 \%$ yang lebih rendah jika dibandingkan dengan penelitian yang dilakukan oleh Goodarzi and Nanekarani (2014) melaporkan bahwa penambahan Mentha pulegium L. pada pakan ayam pedaging dengan level 1-3\% memberikan pengaruh yang nyata terhadap karkas yang dihasilkan. Brenes and Roura (2008) melaporkan bahwa hasil yang berbeda ini disebabkan karena perbedaan sumber dan variasi peppermint yang digunakan meliputi spesies, kandungan bahan aktif, bagian tanaman yang digunakan, waktu pemanenan, metode pengeringan dan bentuk peppermint yang digunakan.

\section{Pengaruh Perlakuan terhadap Persentase Lemak Abdominal Ayam Pedaging}

Tabel 2. menunjukkan nilai rata-rata persentase lemak abdominal ayam pedaging dari yang tertinggi sampai terendah secara berurutan yaitu P1 sebesar $(1,67 \pm 0,41) \%, \quad \mathrm{P}^{-} \quad(1,55 \pm 0,57) \%, \quad \mathrm{P} 3$ $(1,53 \pm 0,28) \%, \mathrm{P}^{+}(1,26 \pm 0,43) \%$ dan $\mathrm{P} 2$ $(1,21 \pm 0,24) \%$. Hasil analisis sidik ragam menunjukkan bahwa pemberian TDM sampai level $1,5 \%$ memberikan pengaruh yang tidak berbeda nyata $(\mathrm{P}>0,05)$ terhadap persentase lemak abdominal ayam pedaging. Persentase lemak abdominal yang tidak berbeda nyata diduga disebabkan karena kinerja dari minyak atsiri yang terdapat pada daun mint (Mentha piperita L.) hampir sama sehingga hasilnya tidak jauh berbeda antar perlakuan. Selain itu, energi metabolis yang diberikan dalam penelitan ini sebesar $3000,33 \mathrm{Kkal} / \mathrm{kg}$ (fase starter) dan 3205,56 $\mathrm{Kkal} / \mathrm{kg}$ (fase finisher) yang jumlahnya hampir sama dengan standar kebutuhan yang direkomendasikan oleh NRC (1994) yaitu kebutuhan energi metabolis ayam ras pedaging sebesar $3200 \mathrm{Kkal} / \mathrm{kg}$.
Konsumsi energi pada ayam antar perlakuan masih relatif sama sehingga belum menimbulkan kelebihan energi untuk kebutuhan hidup pokok. Massolo, dkk. (2016) menyatakan, lemak abdominal terbentuk karena kelebihan kandungan energi yang dikonsumsi oleh ternak serta komposisi pakan juga ikut berpengaruh dalam membentuk lemak tubuh. Tumova dan Teimouri (2010) melaporkan faktorfaktor yang mempengaruhi timbunan lemak abdominal antara lain yaitu genetik, jenis kelamin, umur ayam, nutrisi yang diberikan dan faktor lingkungan.

\section{Pengaruh Perlakuan terhadap Kecerahan $\left(\mathrm{L}^{*}\right)$ Daging Ayam Pedaging}

Tabel 2. menunjukkan nilai rata-rata tingkat kecerahan daging ayam pedaging dari yang tertinggi sampai yang terendah secara berurutan yaitu $\mathrm{P}^{+}$sebesar $(40,54 \pm 1,57), \quad$ P3 $(39,54 \pm 1,74), \quad \mathrm{P}^{-}$ $(39,28 \pm 1,69), \quad$ P1 $(39,22 \pm 1,70)$ dan P2 $(38,84 \pm 1,74)$. Hasil analisis sidik ragam menunjukkan bahwa penggunaan TDM sampai level $1,5 \%$ memberikan pengaruh yang tidak berbeda nyata $(\mathrm{P}>0,05)$ terhadap nilai kecerahan $\left(\mathrm{L}^{*}\right)$ daging ayam pedaging. Tidak berbedanya tingkat kecerahan ( $\left.\mathrm{L}^{*}\right)$ ini diduga disebabkan karena TDM tidak memiliki pigmen warna dan tidak memberikan pengaruh terhadap konsentrasi pigmen mioglobin sehingga menghasilkan tingkat kecerahan $\left(\mathrm{L}^{*}\right)$ yang hampir sama antar perlakuan. Hal ini sesuai dengan pendapat Soeparno (2005) yang menyatakan bahwa warna daging dipengaruhi oleh pigmen daging yang terdiri dua protein yaitu mioglobin pigmen otot dan haemoglobin pigmen darah. Konsentrasi mioglobin akan menyebabkan macam otot merah atau otot putih.

Nilai pH yang dihasilkan dalam penelitian ini hampir sama antar perlakuan yaitu berkisar 5,58-5,68. Semakin rendah nilai $\mathrm{pH}$ maka semakin cerah juga warna dagingnya, hal ini karena daging memiliki struktur terbuka atau longgar yang mengakibatkan cahaya mampu menyebar sehingga daging terlihat lebih cerah. Hal ini 
sesuai dengan Sriyani, Ariana dan Siti (2014) melaporkan pH akhir berpengaruh terhadap nilai warna daging yang dihasilkan. Nilai $\mathrm{pH}$ rendah berkisar antara 5,1-6,1 menyebabkan daya ikat air menjadi kecil akibatnya struktur jaringan otot menjadi renggang dan lebih banyak cahaya yang dipantulkan dibandingkan dengan yang diserap sehingga menghasilkan warna yang lebih pucat.

\section{Pengaruh Perlakuan terhadap Warna Kemerahan (a*) Daging Ayam Pedaging}

Tabel 2. menunjukkan nilai rata-rata warna kemerahan $\left(a^{*}\right)$ daging ayam pedaging dari yang tertinggi sampai yang terendah secara berurutan yaitu $\mathrm{P} 2$ sebesar $(26,30 \pm 4,86), \quad$ P3 $\quad(24,32 \pm 2,28), \quad$ P1 $(23,92 \pm 2,11), \mathrm{P}^{+}(22,94 \pm 0,82)$ dan $\mathrm{P}^{-}$ $(22,30 \pm 1,81)$. analisis sidik ragam pada lampiran 5 menunjukkan bahwa penggunaan TDM sampai level 1,5\% memberikan pengaruh yang tidak berbeda nyata $(\mathrm{P}>0,05)$ terhadap warna kemerahan $\left(a^{*}\right)$ daging ayam pedaging.

Warna kemerahan (a*) daging yang tidak berbeda diduga disebabkan karena penggunaan TDM tidak dapat mempengaruhi konsentrasi mioglobin. Hal ini sesuai dengan penelitian yang dilakukan oleh Abdulkarimi, Abdullahi dan Amini (2011) menyatakan pemberian ekstrak daun mint (Mentha piperita L.) hingga level $0,6 \%$ tidak memberikan pengaruh yang nyata terhadap hemoglobin, hematrosit dan sel darah merah pada ayam pedaging Ross.

Pakan yang tinggi kandungan protein dapat menghasilkan warna daging yang semakin kemerahan. Pakan perlakuan memiliki kandungan protein yang baik yaitu 23,01\% (fase starter) dan 19,50\% (fase finisher), yang jumlahnya hampir sama dengan standar kebutuhan yang telah direkomendasikan oleh NRC (1994) yang menyatakan kebutuhan protein ayam ras pedaging fase starter $23 \%$, sedangkan fase finisher sebesar 20\%. Konsumsi protein dalam setiap perlakuannya sama sehingga hasil warna kemerahan $\left(b^{*}\right)$ daging menunjukkan perbedaan yang tidak nyata $(\mathrm{P}>0,05)$.

\section{Pengaruh Perlakuan terhadap Warna Kekuningan (b*) Daging Ayam Pedaging}

Tabel 2. menunjukkan nilai rata-rata warna kekuningan $\left(b^{*}\right)$ daging ayam pedaging dari yang tertinggi sampai yang terendah secara berurutan yaitu $\mathrm{P}^{+}$sebesar $(6,44 \pm 1,90), \quad$ P3 $\quad(4,54 \pm 2,40), \quad$ P1 $(4,26 \pm 2,40), \quad \mathrm{P}^{-} \quad(4,00 \pm 0,80)$ dan $\mathrm{P} 2$ $(2,30 \pm 1,70)$. Hasil analisis sidik ragam menunjukkan bahwa penggunaan TDM sampai level $1,5 \%$ memberikan pengaruh yang tidak berbeda nyata $(\mathrm{P}>0,05)$ terhadap nilai kekuningan daging ayam pedaging.

Tidak berbedanya warna kekuningan (b*) daging ayam pedaging ini diduga disebabkan karena rendahnya kandungan karoten dalam daun mint. Rubinskie, et al. (2015) melaporkan daun mint segar mengandung karoten sebesar 5,7 mg/100 g sehingga penambahan tepung daun mint tidak berpengaruh terhadap warna kekuningan $\left(b^{*}\right)$ daging ayam pedaging. Lesson andSummers (2000) menambahkan bahwa pigmentasi pada masa pertumbuhan ayam pedaging berasal dari pimen pakan, sehingga pakan yang diberikan menjadi faktor utama dalam menentukan warna daging yang dihasilkan. Hasil yang tidak berbeda nyata diduga juga disebabkan karena daun mint mengalami proses pengering-anginan yang dapat menyebabkan kandungan karoten dalam daun mint menjadi berkurang bahkan mengalami kerusakan sehingga kurang mempengaruhi warna kekuningan $\left(b^{*}\right)$ daging. Kusbandari dan Susanti (2017) melaporkan bahwa $\beta$-karoten memilki karakteristik yaitu larut dalam lemak tetapi tidak larut dalam air dan mudah mengalami kerusakan apabila mengalami proses pemanasan dengan suhu tinggi.

\section{KESIMPULAN}

Penggunaan daun mint (Mentha piperita L.) belum dapat memperbaiki kualitas karkas ayam pedaging yang 
meliputi persentase karkas, persentase lemak abdominal dan warna daging. Perlakuan terbaik terdapat pada P3 apabila dilihat dari segi persentase karkas yang dihasilkan yaitu sebesar 64,03\%. Penggunaan daun mint (Mentha piperita L.) disarankan untuk menggunakan teknologi ekstraksi agar penggunaannya lebih efektif dalam memperbaiki kualitas karkas ayam pedaging.

\section{DAFTAR PUSTAKA}

(NRC), N. R. C. (1994). Nutrient requirement of poultry. Washington, D.C: National Academy Press.

Abdulkarimi. Rahim, Aghazadeh, A., \& Daneshyar, M. (2012). Effect of mentha extract (Mentha piperita) supplementation in drinking water on performance, plasma lipoproteins, carcass charasteristic \& liver color index or weight in broiler chickens. The Indian Journal of Animal Sciences, 82(9), 1070-1074.

Antal, T., Figiel, A., Kerekes, B., \& Sikolya, L. (2011). Effect of drying methods on the quality of the essential oil of spearmint leaves ( Mentha spicata L.). Drying Technology, 29(15), 1836-1844. https://doi.org/10.1080/07373937.201 1.606519

Brenes, A., \& Roura, E. (2010). Essential oils in poultry nutrition: main effects\& modes of action. Animal Feed Science \& Technology, 158(12), $1-14$. https://doi.org/10.1016/J.ANIFEEDS CI.2010.03.007
Figueroa Pérez, M. G., Rocha-Guzmán, N. E., Mercado-Silva, E., Loarca-Piña, G., \& Reynoso-Camacho, R. (2014). Effect of chemical elicitors on peppermint (Mentha piperita) plants $\&$ their impact on the metabolite profile \& antioxidant capacity of resulting infusions. Food Chemistry, 156 , 273-278. https://doi.org/10.1016/j.foodchem.20 14.01.101

Goodarzi, M., \& Nanekarani, S. (2014). Effects of feeding mentha pulegium 1. as an alternative to antibiotics on performance of broilers. APCBEE Procedia, 8, 53-58. https://doi.org/10.1016/J.APCBEE.20 14.01.079

Khempaka, S., Pudpila, U., \& Molee, W. (2013). Effect of dried peppermint (Mentha cordifolia) on growth performance, nutrient digestibility, carcass traits, antioxidant properties, $\&$ ammonia production in broilers. The Journal of Applied Poultry Research, 22(4), 904-912. https://doi.org/10.3382/japr.201300813

Kusb\&ari, A., \& Susanti, H. (2017). Kandungan beta karoten \& aktivitas penangkapan radikal bebas terhadap DPPH (1,1-difenil 2-pikrilhidrazil) ekstrak buah blewah (Cucumis melo var. Cantalupensis L) secara spektrofotometri UV-Visibel. Journal of Pharmaceutical Sciences \& Community, 14(1), 37-42. https://doi.org/10.24071/jpsc.141562

Leeson, S., \& Summers, J. D. (1980). Production \& carcass characteristics of the broiler chicken. Poultry Science, 59(4), 786-798. https://doi.org/10.3382/ps.0590786 
Massolo, R., Mujnisa, A., \& Agustina, L. (2017). Persentase karkas \& lemak abdominal broiler yang diberi prebiotik inulin umbi bunga dahlia (Dahlia variabillis). Buletin Nutrisi \& Makanan Ternak, 12(2).

Siswi, N. P., Widodo, E., \& Djunaidi, I. H. (2014). Pengaruh penambahan sari jahe merah (Zingiber Officinale var Rubrum) terhadap kualitas karkas Itik pedaging.

Sriyani, T., Ariana, P., \& Siti. (1970). Pengaruh pakan daun pepaya (Carica papaya L.) terhadap kualitas fisik daging kambing bligon. Majalah Ilmiah Peternakan, 17(3), 91-94. https://doi.org/10.24843/MIP.2014.v1 7.i03.p03
Tsai, M., Wu, C., Lin, T., Lin, W., Huang, Y., \& Yang, C. (2013). Chemical composition \& biological properties of essential oils of two mint species. Tropical Journal of Pharmaceutical Research, 12(4), 577-582. https://doi.org/10.4314/tjpr.v12i4.20

Tumova, A., \& Teimouri, A. (2010). Fat deposition in the broiler chicken:A Review. Scientia Agriculturae Bohemica, 41(2), 121-128.

Weaver, C. (1996). The food chemistry laboratory(Boca Raton). Tokyo: CRC Press. 